\title{
FIELD TRIALS ON THE SOIL CEMENT MIXING TECHNOLOGY TO REINFORCE EARTH LEVEES IN THE MEKONG DELTA, VIETNAM
}

\author{
Hoang-Hung Tran-Nguyen, Long Phi Le ${ }^{1}$, Bao Khac Le, and Hien Minh Thi Ly
}

Department of Bridge and Highway Engineering, Faculty of Civil Engineering, Ho Chi Minh City University of Technology (HCMUT), Ho Chi Minh City, Vietnam, e-mail: tnhhung@hcmut.edu.vn

Received Date: May 14, 2017

\begin{abstract}
The effectiveness of seepage cutoff and sliding stability of an earth levee reinforced by soil cement deep mixing technology (SCDM) was evaluated by field monitored data. Groundwater observation was conducted via nine ground water wells installed in the research site. Lateral displacement of the whole earth levee was measured by the $15-\mathrm{m}$ inclinometer casing and a $0.5-\mathrm{m}$ inclinometer probe. The research assessed effects of soilcrete reinforcement by comparing with simulations before applying widely in the Mekong Delta, Vietnam. The results indicate that the soilcrete walls can effectively prevent the seepage through the earth levee's body and improve the factor of safety about 1.2 times.
\end{abstract}

Keywords: Earth levee, Seepage, Sliding, Slope, Soil cement mixing, Soilcrete, Stability

\section{Introduction}

Earth levees have been constructed in Mekong delta to protect rice fields against annual floods from Mekong river. Hundreds of kilometers long earth levees required maintenance yearly [1]. Dredging materials taken from rivers along the earth levees are the key fill materials for their constructions. The dredging materials are being used to maintain the elevation of earth levees above the floodwater at least $0.5 \mathrm{~m}$ every year. Typically, earth levees in Mekong delta filled with least compaction. Therefore, earth levees are quite sensitive to high floodwaters and less stable against annual floods. Piping which is erosion inside earth levees due to seepage flows from floodwater and sliding are the two main factors causing earth levee's failures [2]. The current techniques such as timber piles, sandbags, or gabion stones have temporarily reinforced earth levees.

Soilcrete walls or soil cement deep mixing (SCDM) walls with lower hydraulic conductivity and higher strength than those of the in-situ soils have potential to cut off seepage flows and to improve sliding stability [3] for the earth levees but still have limit applications. The SCDM technology was developed in 1950s and first applied in Vietnam in 2000s for improving highway embankments on soft ground. Therefore, researches for applying the SCDM technology massively and effectively to reinforce earth levees against annual floods are necessary.

This paper investigated effectiveness of field soilcrete walls created by the SCDM technology from data obtained via field monitoring systems. A 30-m soilcrete wall was constructed at the "September $2^{\text {nd" }}$ earth levee in An Hoa ward Tam Nong district Dong Thap province for a field experiment on the SCDM technology in the Mekong Delta. The field monitoring systems consisting of groundwater observation wells and an inclinometer 
casing were built at the research site. The groundwater observation wells monitored seepage across the earth levee's body during a flood season with and without reinforcement of the soilcrete walls. The inclinometer casing provides lateral displacement of the earth levee's body toward the riverside and rice field side. The field-monitored data were acquired 2-4 times per month for a flood cycle which is a 12-month period.

\section{Research}

A 30-m trial construction to create two soilcrete walls was chosen at a section of the "September $2^{\text {nd" }}$ (2/9) earth levee in An Hoa ward, Tam Nong district, Dong Thap province to demonstrate how the SCDM technology reinforce earth levees in the Mekong Delta (Figure 1). The 2/9 earth levee is one of typical earth levees in the Mekong Delta, and this research result can be appropriately applied for the whole Mekong Delta. The 2/9 earth levee has 3-5 m width and the earth levee crest of $+5 \mathrm{~m}$ above the sea level. A 25-m borehole was drilled at the research site to investigate soil properties along a 25-m soil profile. Key soil properties are given in Table 1.

Table 1. Key Soil Properties Along the 25-m Soil Profile [4]

\begin{tabular}{lcccc} 
Soil Properties & Medium Clay & Soft Clay & Stiff Clay & $\begin{array}{c}\text { Stiff Clay } \\
\text { with Gravel }\end{array}$ \\
\hline Thickness $(\mathrm{m})$ & 4.6 & 2.9 & 7.0 & 10.5 \\
Hydraulic conductivity $(\mathrm{m} / \mathrm{s})$ & - & $3.29 \times 10^{-8}$ & $1.57 \times 10^{-8}$ & $1.23 \times 10^{-8}$ \\
Natural unit weight $\left(\mathrm{kN} / \mathrm{m}^{3}\right)$ & 19.36 & 16.03 & 20.26 & 19.74 \\
Cohesion $\left(\mathrm{kN} / \mathrm{m}^{2}\right)($ direct shear) & 23.9 & 7.6 & 14.8 & 27.2 \\
Friction angle (degree) & $13.95^{0}$ & $6.53^{0}$ & $18.48^{0}$ & $17.25^{0}$ \\
(Direct shear) & & &
\end{tabular}

a) A research site (Google Maps)

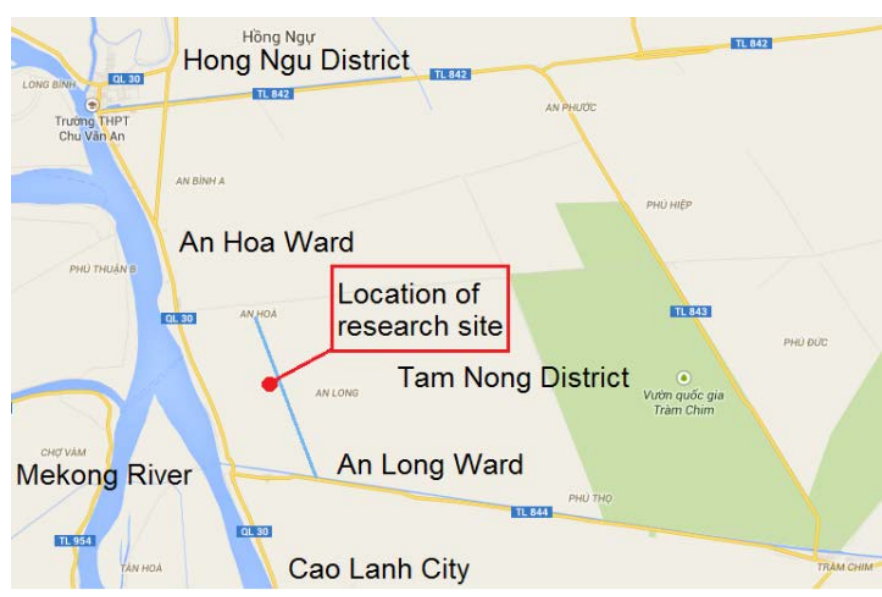

(b) A tested section of the 2/9 earth levee

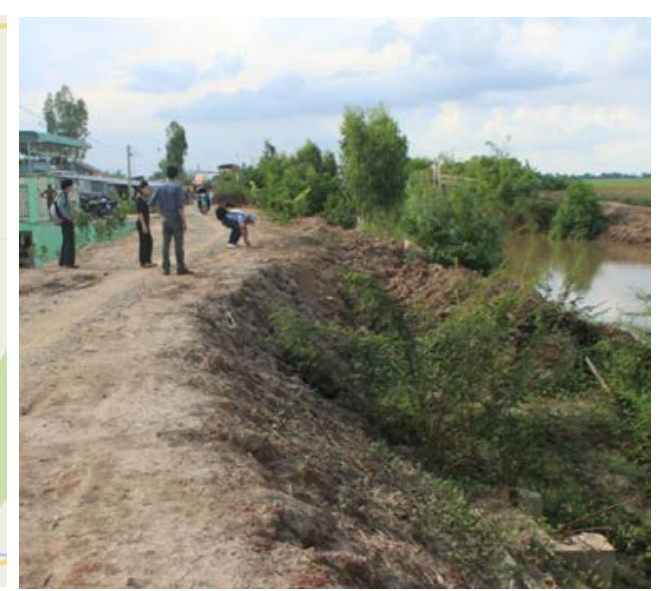

Figure 1. A tested earth levee in the 2/9 earth levee in An Hoa ward, Tam Nong district, Dong Thap province

\section{Methodology}

\section{Slope stability analysis}

Factor of Safety, FS, is used to evaluate sliding stability of an earth levee and is defined by Equation (1). 
$F S=\frac{\tau_{f}}{\tau}$

where $\tau_{f}=(\sigma-u) \tan \phi^{\prime}+c^{\prime}$ - effective shear strength of the soil mass, $\tau$ - shear stress of the soil mass; $\sigma, c^{\prime}, \varphi^{\prime}, u$ - total stress, effective cohesion, effective friction angle, and pore water pressure, respectively.

In this study, the Simplified Bishop method was utilized for sliding analysis and FS is computed by Equation (2) (Figure 2) [14]. According to the 22 TCN 262-2000 - a Vietnam code [6], a FS should be larger than 1.4 to be considered as stable.

$$
F S=\frac{\sum\left[c^{\prime} b_{i}+\left(W_{i}-u_{i} \times b_{i}\right) \times \tan \phi^{\prime}\right] \times \frac{1}{m_{\alpha(i)}}}{\sum W_{i} \sin \alpha_{i}}
$$

where $b_{i}$ - slice width; $W_{i}$ - weight of each slice; $\alpha_{i}$ - incline of a slice base to horizontal direction; $u_{i}$ - pore water pressure in each slice; $m_{\alpha(i)}=\cos \alpha_{i}+\frac{\tan \phi^{\prime} \times \sin \alpha_{i}}{F S}$

(a) Slices of a potential circular failure surface

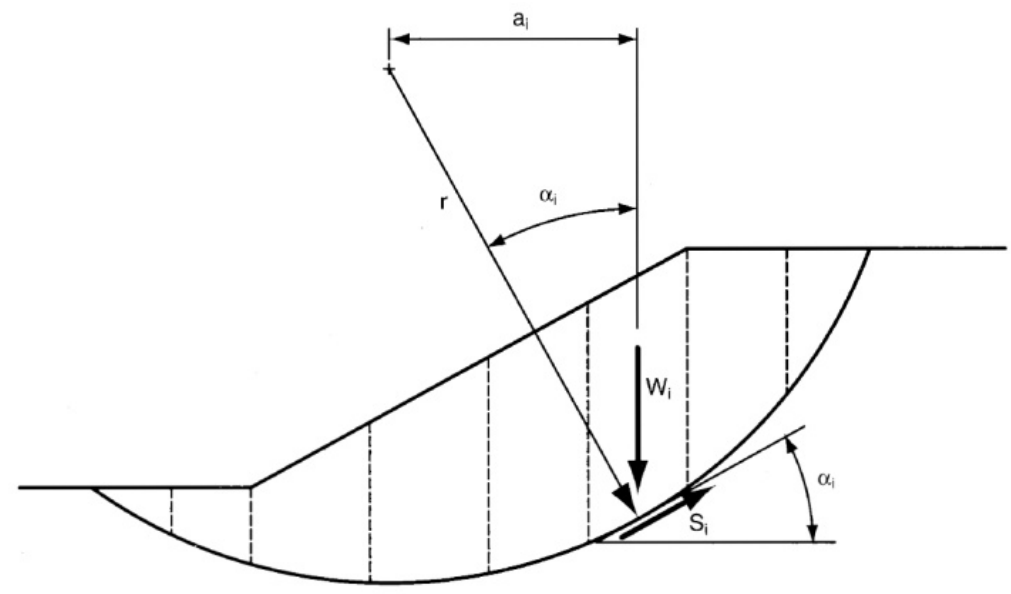

(b) Forces on each slice

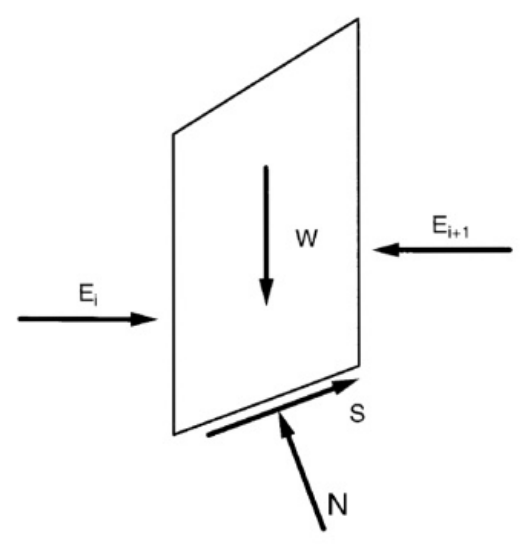

Figure 2. The Simplified Bishop method to determine FS for sliding analysis [14]

\section{Groundwater observation}

In principle, groundwater observation wells are installed to obtain groundwater fluctuation which is the same as water levels in the wells. Figure 3 shows a design of groundwater observation wells and an illustration to measure water levels in the wells. The groundwater fluctuation indicates seepage status inside an earth levee, especially in flood seasons. It is important to know how groundwater changes inside earth levee because groundwater directly affects stability of an earth levee (see Equation 2).

\section{Lateral displacement measurement}

Sliding is a phenomenon that a soil mass moves laterally toward its slope direction with significant speed. The soil mass moves in depth and in width. An inclinometer casing once installed will move synchronously with the soil mass. Thus, the change of the inclinometer casing will describe movement of the soil mass. An inclinometer probe is used to measure 
the deformation of the inclinometer casing caused by the movement of the soil mass. Figure 4 demonstrates how an inclinometer probe is used to measure lateral displacement of the soil mass. In fact, an inclinometer probe measures inclined angles of the casing along its length, and Equation (3) explains how to determine lateral displacement of an inclinometer casing obtained from an inclinometer probe

$d_{i}=L \times \sin \theta_{i}$

where $d_{i}$ - lateral displacement at a measured distance of $L ; L$ - distance between the two base wheels of an inclinometer probe; $\theta_{i}$ - inclined angle obtained by an inclinometer probe.

(a) An observation well

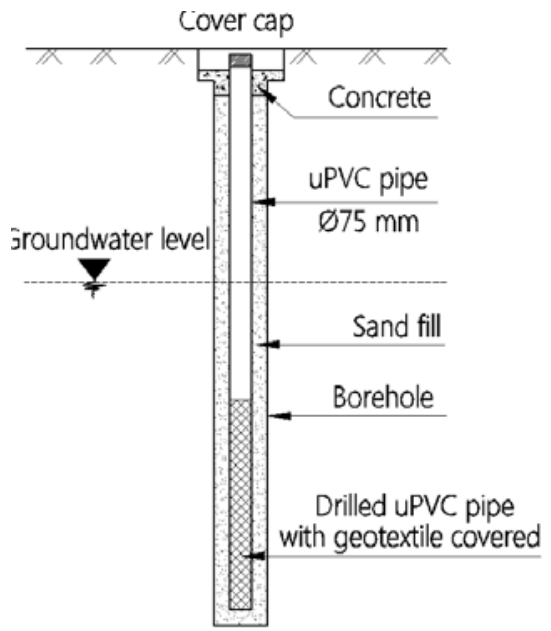

(b) A water level indicator

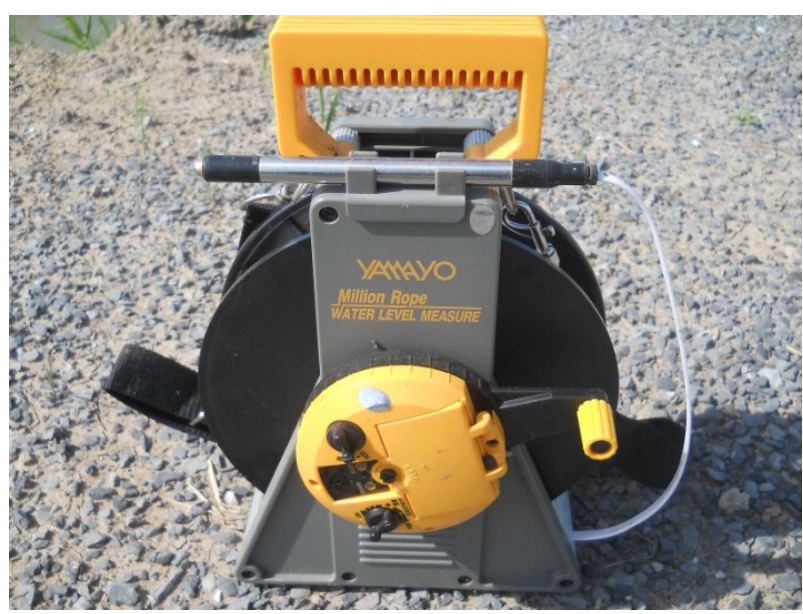

(c) Field groundwater measurement

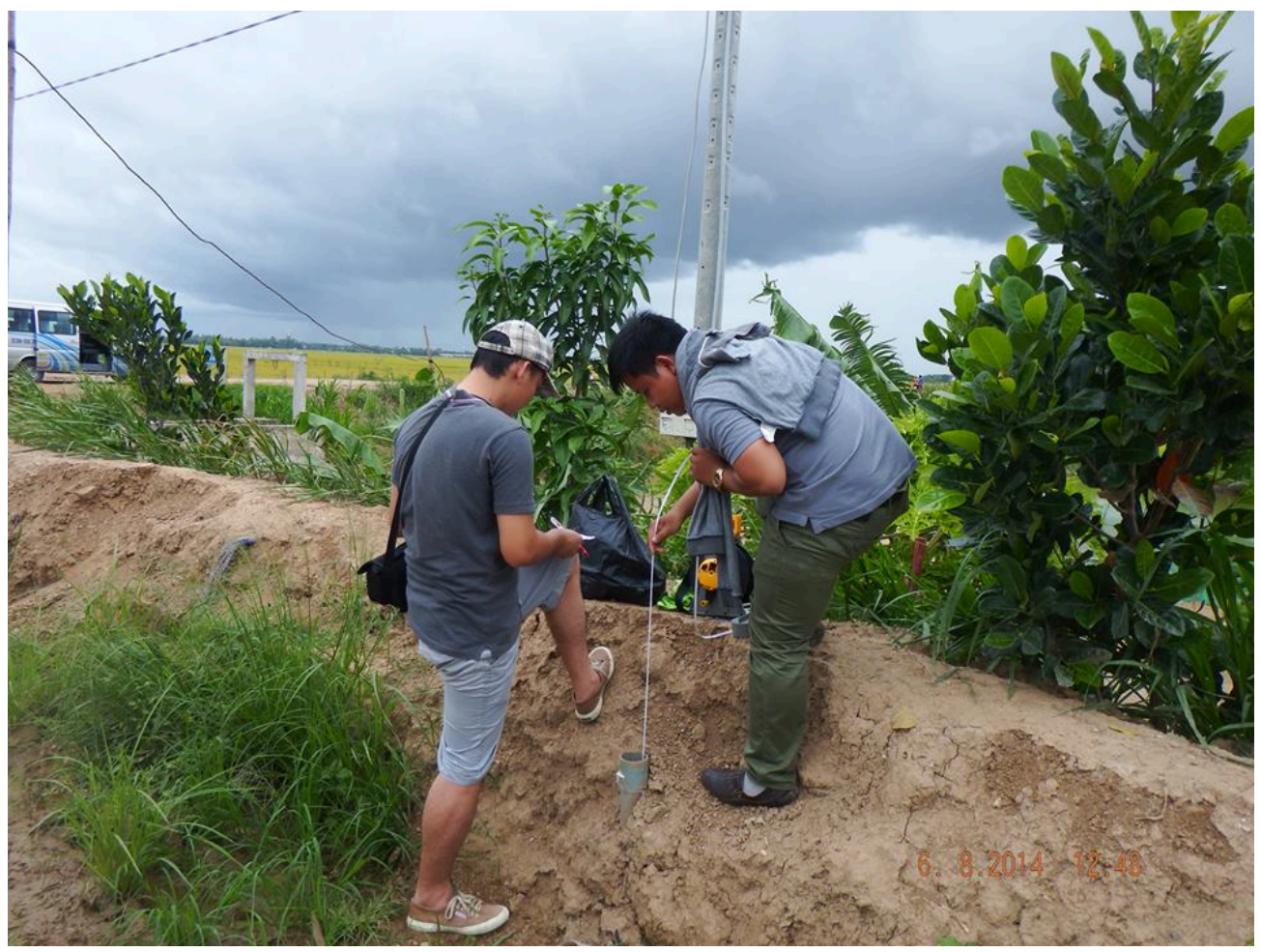

Figure 3. Groundwater observation: design and measurement 


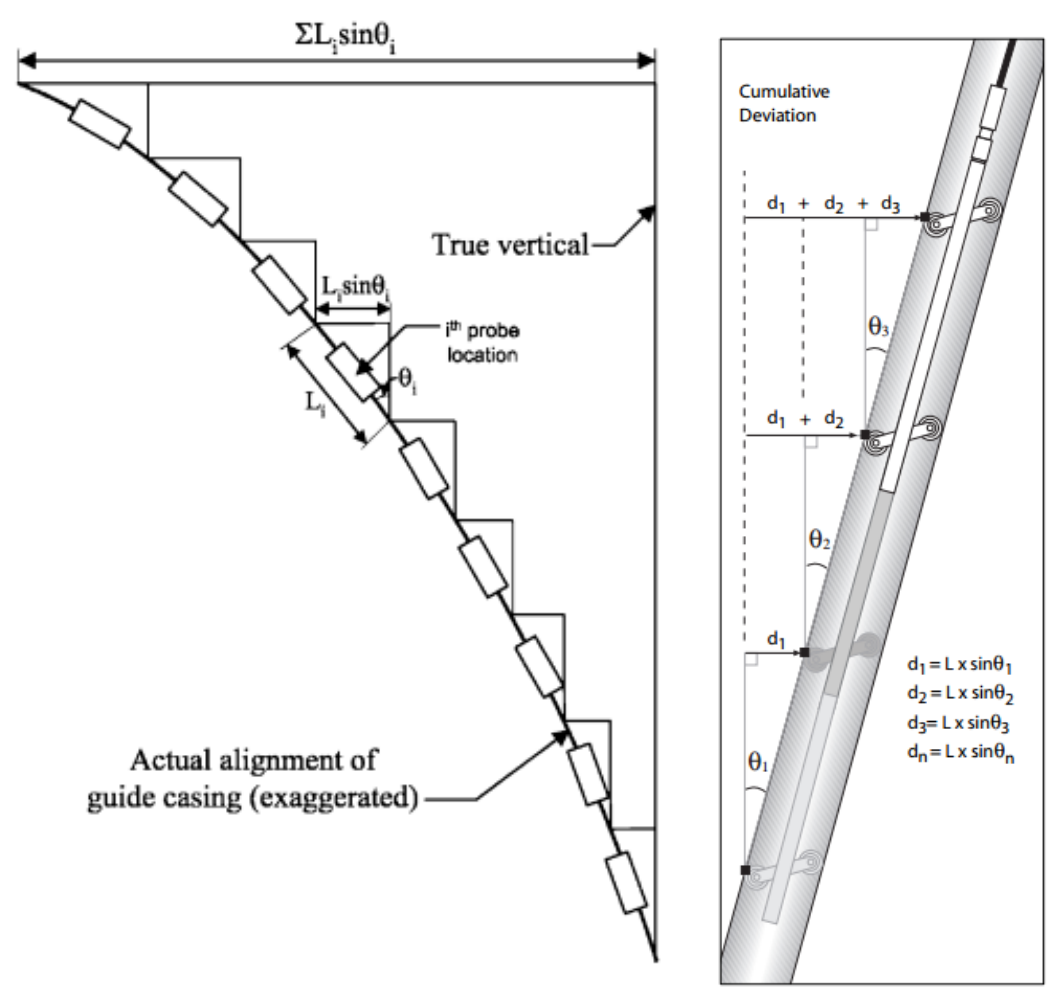

Figure 4. Lateral displacement from inclinometer data (Dunnicliff (1998) from [7])

\section{Design and Construction}

\section{Design of soilcrete walls for earth levees’ reinforcement}

Le Khac Bao et al. $[8,9]$ reported implementation of the SCDM technology to reinforce a 30-m section of the "September $2^{\text {nd" }}$ earth levee in An Hoa ward, Tam Nong district, Dong Thap province. Based on the slope stability and seepage analyses, Le Khac Bao et al. [8, 9] proposed two options to reinforce the earth levee: (1) a 15-m single row overlapped soilcrete columns, and (2) a 15-m double row parallel tangent soilcrete columns (Figure 5).

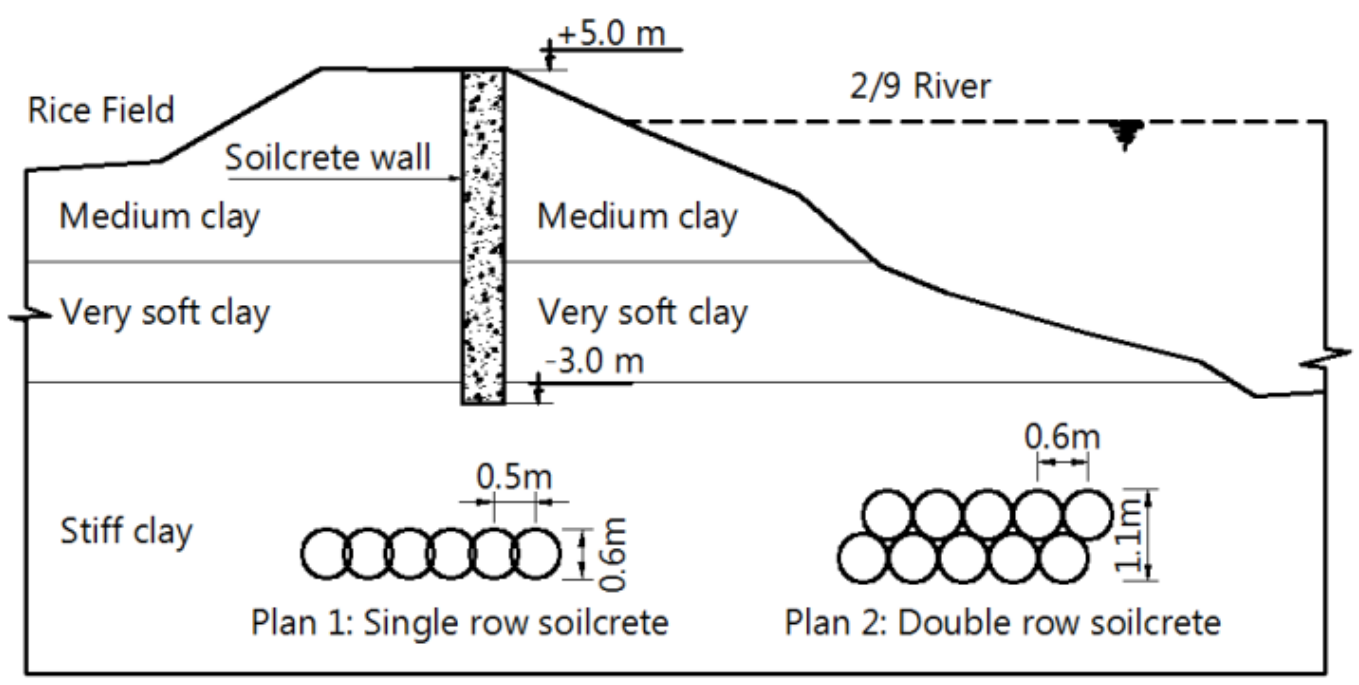

Figure 5. The design for the reinforced earth levee using the SCDM technology [8, 9] 


\section{Trial construction}

A 30-m earth levee of the 2/9 earth levee was constructed for a field experiment on the SCDM technology in An Hoa ward, Tam Nong district, Dong Thap province. The trial construction was divided into 2 15-m sections (Figure 5 and 6). The trial construction process was reported by Le Phi Long et al. (2015) in detail [10].

- Section 1: a 15-m soilcrete wall with $8 \mathrm{~m}$ deep was formed from a double row soilcrete column. A NSV system creates $0.6-\mathrm{m}$ diameter soilcrete parallel tangent columns with a cement content of $250 \mathrm{~kg} / \mathrm{m}^{3}$.

- Section 2: right after the section 1, a 15-m soilcrete wall with $8 \mathrm{~m}$ deep was created using the NSV system to form a single row soilcrete tangent column with a diameter of $0.6 \mathrm{~m}$ and a cement content of $300 \mathrm{~kg} / \mathrm{m}^{3}$. Two pilot soilcrete columns with cement contents of 150 and $200 \mathrm{~kg} / \mathrm{m}^{3}$ were respectively conducted at the beginning of the section 2 .

(a) Plan view of the monitoring systems

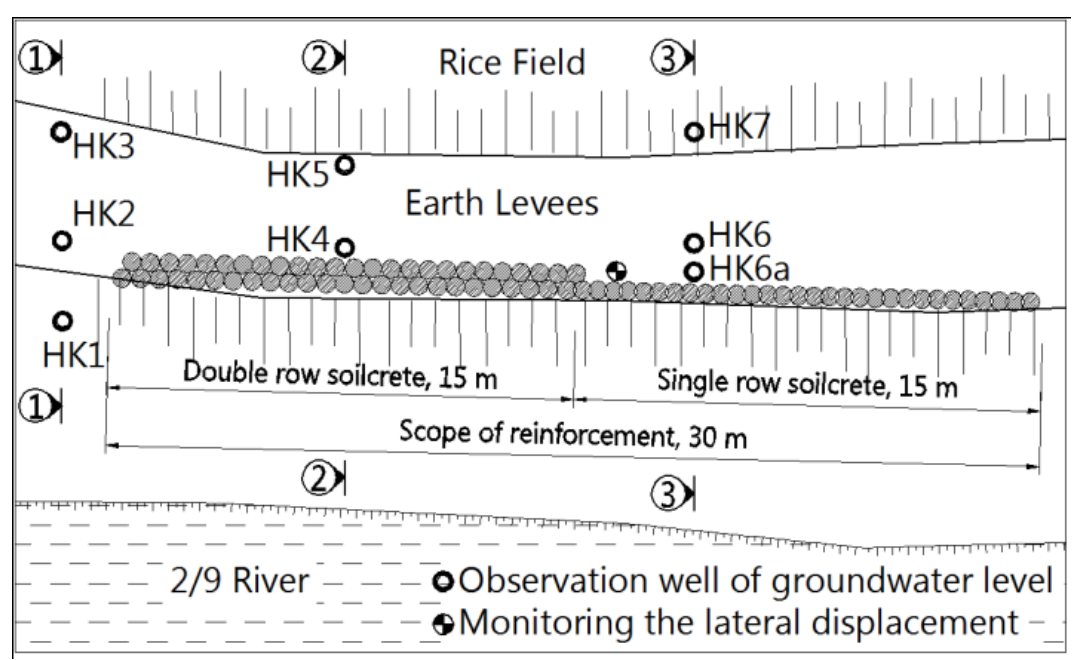

(b) Arrangement of soilcrete columns

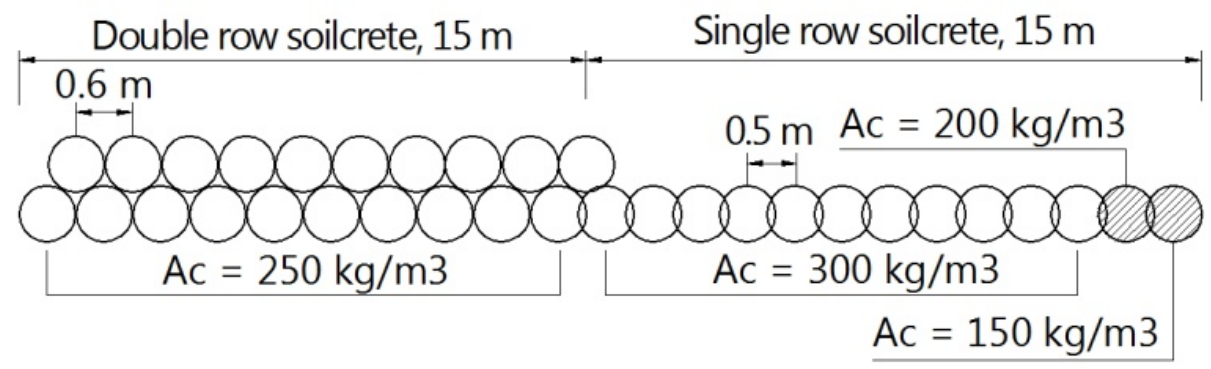

Figure 6. The trial construction for the tested earth levee [10]

\section{Installation of Field Monitoring Systems}

\section{Groundwater observation wells}

For monitoring groundwater fluctuation inside an earth levee, 8 observation wells were installed at the research site (Figure 6a). Three wells (HK1, HK2, HK3) were constructed at 
a cross section \#1 locating outside the reinforced earth levee. The cross section \#1 provides groundwater levels across the earth levee without reinforcement. A cross section \#3 has HK6a and HK7 wells (HK6 was damaged after the pilot construction done) to monitor groundwater across the double row soilcrete wall. A cross section \#2 consists of HK4 and HK5 wells to supervise groundwater across the single row soilcrete wall. All observation wells were made from $\phi 75 \mathrm{~mm}$ PVC plastic pipes with $6 \mathrm{~m}$ long each well. The elevation of the well tip was $-1.0 \mathrm{~m}$ which is below the lowest water level of $+0.3 \mathrm{~m}$ in the river. Figure 7 shows an installation process of the observation wells at the field.

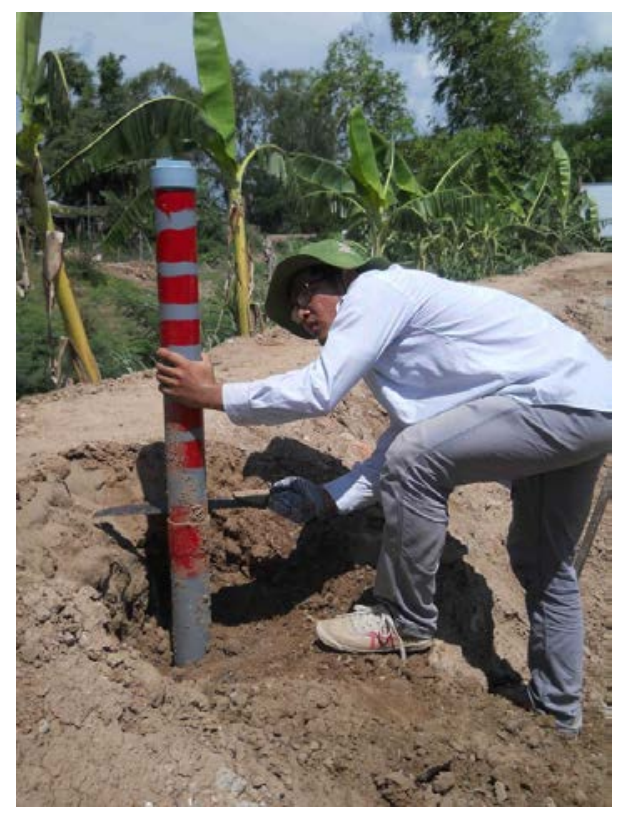

Figure 7. Groundwater observation wells installed at the field

\section{Inclinometer casing}

A 12-m inclinometer casing with a diameter of $70 \mathrm{~mm}$ (Slope indicator, USA) was installed at a distance of $0.5 \mathrm{~m}$ from the single row soilcrete wall inside the earth levee body. The inclinometer casing is always dry inside to avoid damage of an inclinometer probe during measurement. Inclinometer casing was made of ABS plastic and was lengthened from 3-m segments (Figure 8).

(a) Inclinometer casing

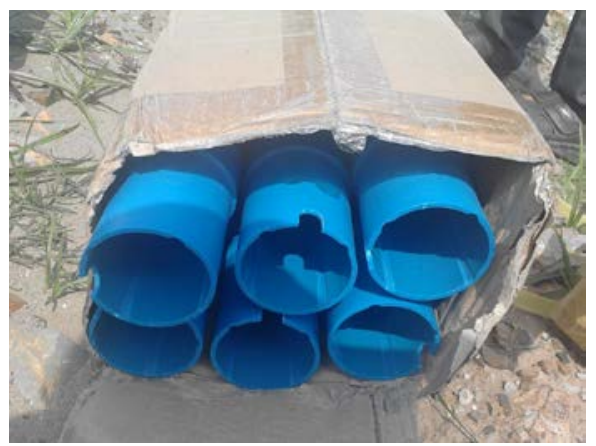

(b) Example of installation process [12]

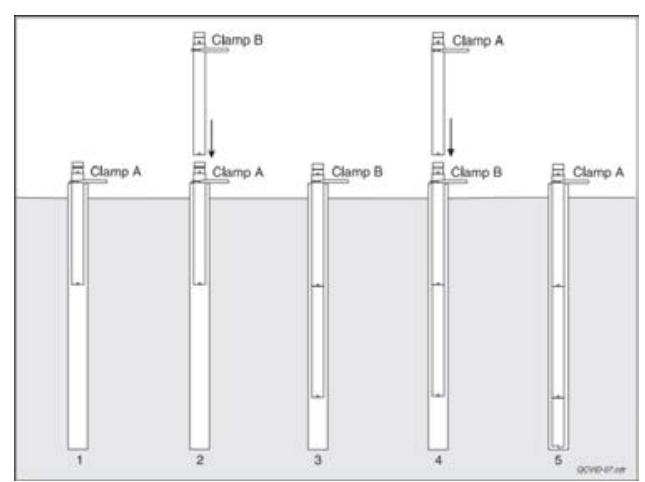

Figure 8. Installation of inclinometer casing at the field 


\section{Results}

\section{Groundwater}

Figure 9 shows the groundwater fluctuation across the earth levee monitored from July 2013 to January 2015 at the research site. The field data was obtained by 2-4 times per month using a water level indicator (Yamayo RWL-50) (Figure 3b). The blue lines show the groundwater levels and the black lines indicate the ground surface or the boundaries of the soil layers.

(a) Measurement without reinforcement

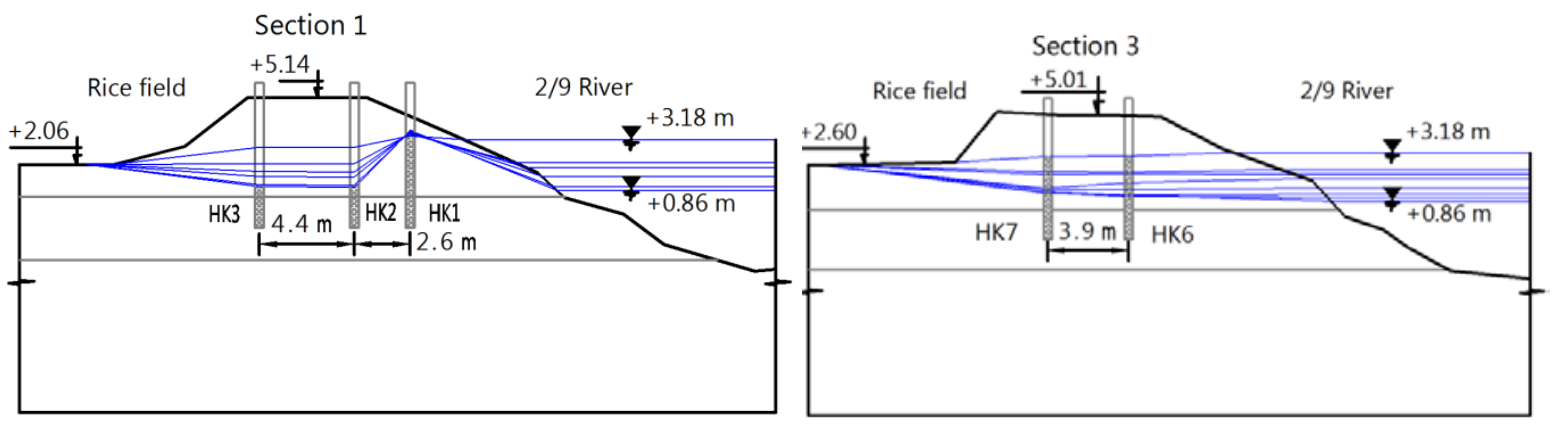

(b) Measurement with soilcrete walls reinforcement
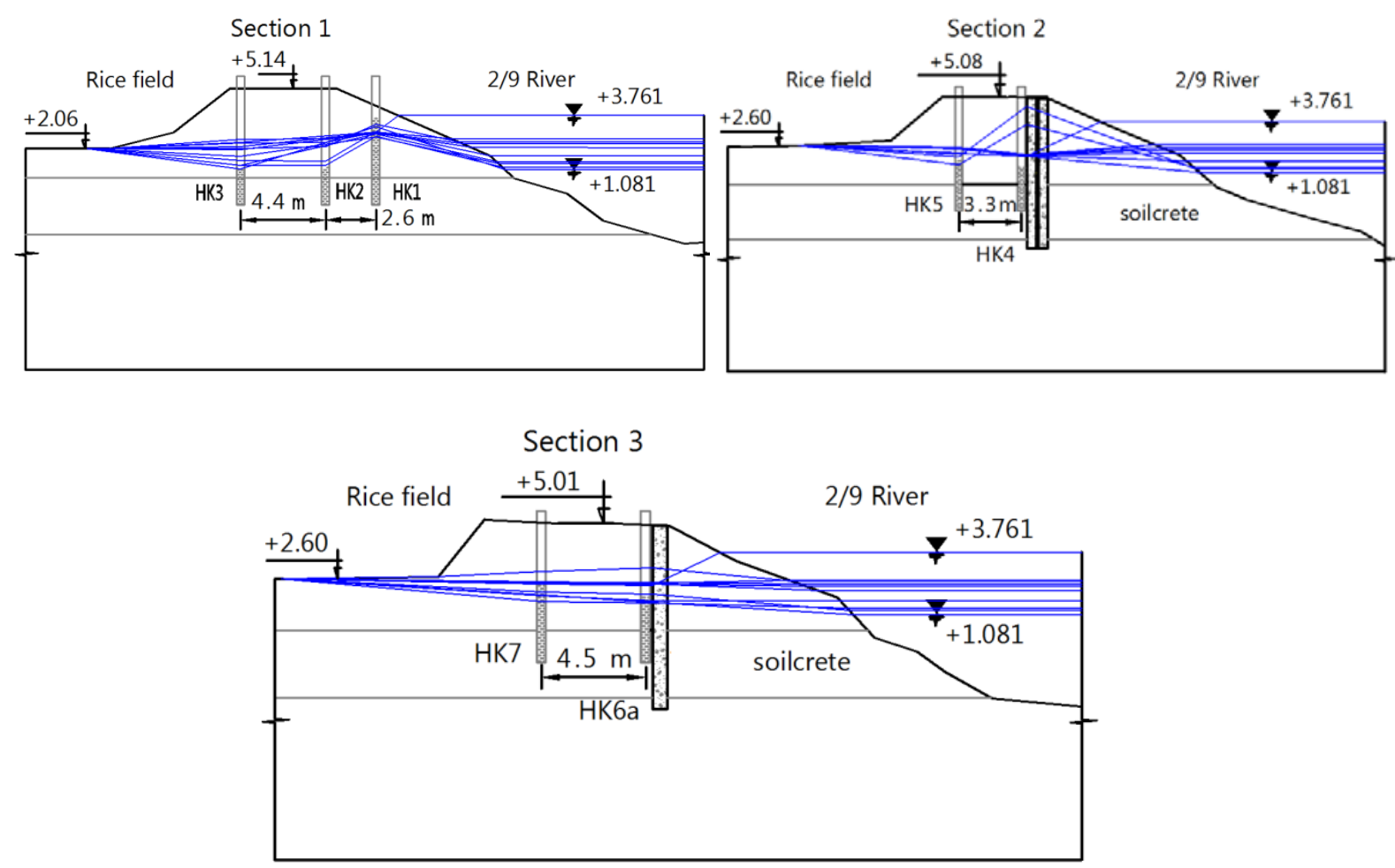

Figure 9. Groundwater levels measured at the site from July 2013 to January 2015

\section{Sliding analysis}

To evaluate sliding stability of the reinforced earth levee, sliding analysis was conducted using the Slope/W 2007 software and the filed monitored data. Soilcrete parameters were obtained from unconfined compressive strength tests of specimens taken at the field reported 
by Le Phi Long et al. [10] (Table 2). Six options were selected for sliding analysis of the tested earth levee: (1) without reinforcement; (2) reinforced by the single row soilcrete wall; (3) reinforced by the double row soilcrete wall; and consider the highest and lowest monitored water levels in the river. The sliding analysis also investigated sliding possibility toward the river and toward the rice field. The results of the sliding analysis are shown in Table 3.

Table 2. Soilcrete Parameters Obtained from the USC Tests [9]

\begin{tabular}{|c|c|c|c|}
\hline Reinforcement & $\begin{array}{c}\text { Natural unit } \\
\text { weight, } \\
\gamma\left(\mathbf{k N} / \mathbf{m}^{3}\right)\end{array}$ & $\begin{array}{c}\text { Friction } \\
\text { angle, } \\
\phi\left({ }^{0}\right)\end{array}$ & $\begin{array}{c}\text { Cohesion } c \\
\left(\mathrm{kN} / \mathrm{m}^{2}\right)\end{array}$ \\
\hline oilcrete wall & 17 & 0 & 850 \\
\hline Double row soilcrete wall & 17 & 0 & 700 \\
\hline
\end{tabular}

There are the two lowest water levels. The $+0.86 \mathrm{~m}$ is the historic level, and the $+1.08 \mathrm{~m}$ is the lowest monitored level after the reinforcement. The slope stability analysis was conducted to confirm that the earth levee is stable for a flood cycle which is 6-month monitor. It is noted that an additional surcharge taking account for light trucks (e.g., $\leq 2.5$ Tons) was included in sliding analysis. The surcharge of $3.4 \mathrm{kPa}$ was equivalent the total load of a truck distributing on the surrounding area of the four wheels.

Table 3. Sliding Analysis Using the Slope/W 2007 Software and the Field Monitored Data

\begin{tabular}{llcc}
\multirow{2}{*}{ Analysis options } & & \multicolumn{2}{c}{ FS } \\
\cline { 3 - 4 } & & River Side & Paddy Side \\
\hline \multirow{2}{*}{$\begin{array}{l}\text { The lowest water level in } \\
\text { the river +1.08 m }\end{array}$} & No reinforcement & 1.09 & 2.41 \\
& Single row soilcrete wall & 1.60 & 2.52 \\
& Double row soilcrete wall & 1.91 & 3.10 \\
\hline \multirow{2}{*}{$\begin{array}{l}\text { The highest water level in } \\
\text { the river +3.76 m }\end{array}$} & No reinforcement & 1.23 & 2.29 \\
& Single row soilcrete wall & 2.13 & 2.55 \\
& Double row soilcrete wall & 2.38 & 3.06 \\
\hline
\end{tabular}

Without reinforcement, FS was lower than 1.4 but still larger than unit (Table 3), that is, the earth levee was stable but has high potential sliding. After reinforced, FS improved to meet the requirements (22 TCN 262-2000) because the soilcrete walls provided a high strength zone (Table 2) against shear failure.

\section{Lateral displacement}

Lateral displacement of the soil mass of the reinforced earth levee was measured from June 2013 to January 2015 using an inclinometer system (Figure 10). During the flood season 2014 which is from August to November, two measurements were conducted every month. Figure 11 shows the lateral displacement monitored using the inclinometer system.

The same first monitored results were conducted during the highest water level in the river which is in the flood season. The water level in the paddy was maintained low. The water level in the river may act as an additional lateral force causing the earth levee to move toward the paddy side. 

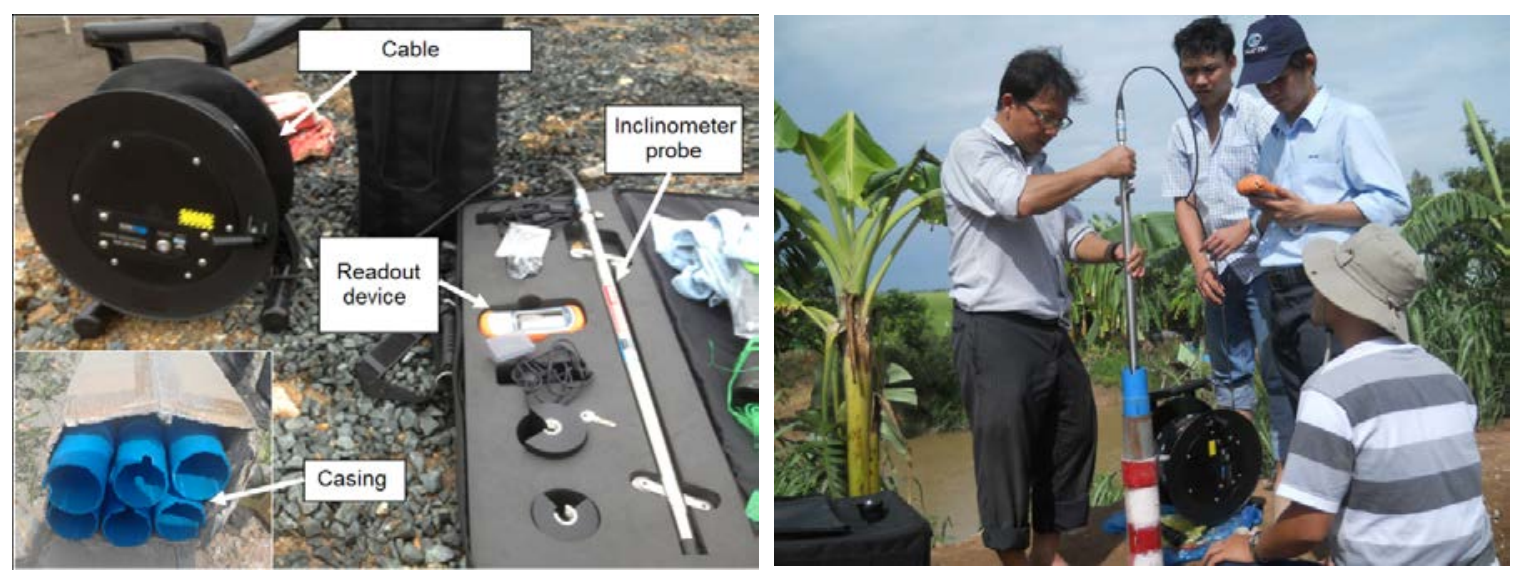

Figure 10. An inclinometer kit used to monitor lateral displacement of the reinforced earth levee

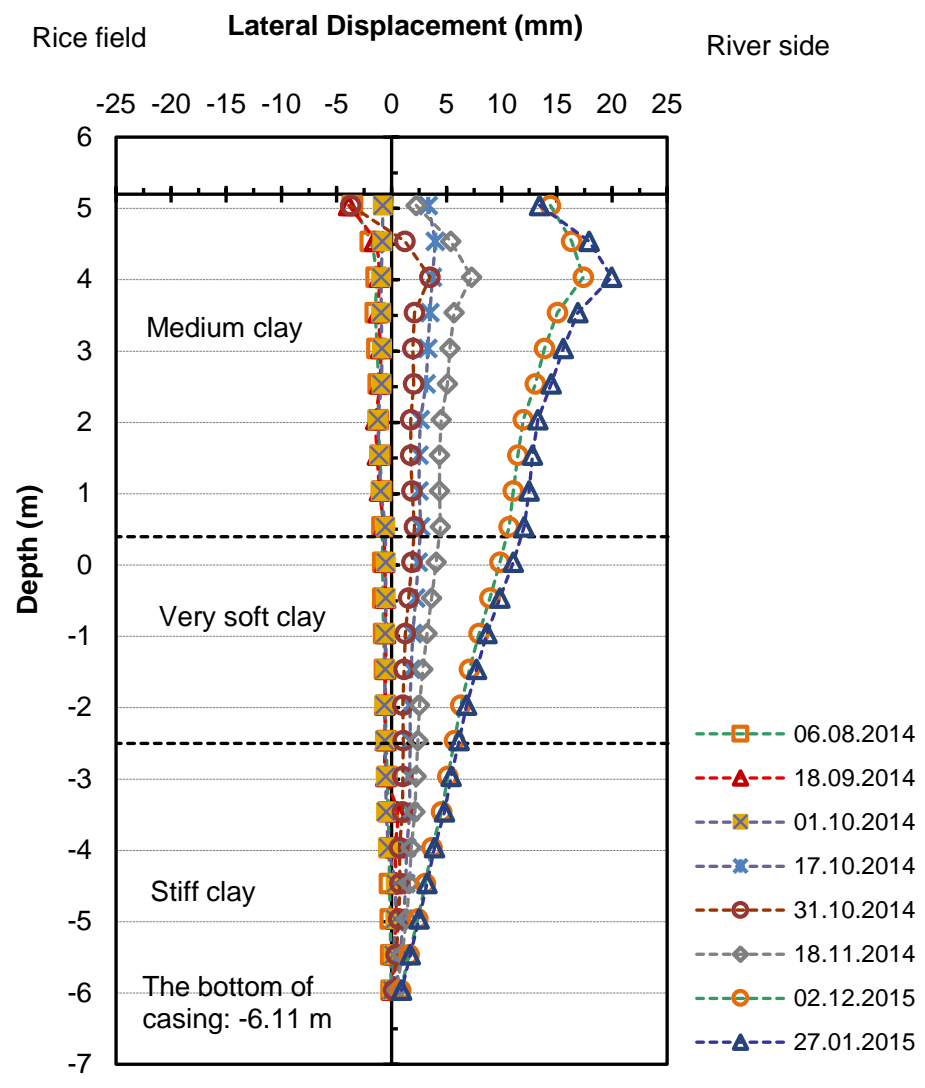

Figure 11. Monitored lateral displacement over a flood cycle which is 6 months

The depth of the inclinometer casing is embedded in the soil mass over a critical failure surface around 2-3 m. Slope stability analysis was as shown in Figure 12. The inclinometer casing was $12 \mathrm{~m}$ long which is deeper the critical failure surface about $3 \mathrm{~m}$. This requirement expects that the upper part of the casing, which is above a critical failure surface, moves synchronically with the soil mass and the lower part plays an anchor role. However, the monitored data indicates that the bottom of the casing seems to move 
simultaneously with the soil mass. The coordinate of the top of the inclinometer casing was measured to verify with the lateral displacement obtained by the inclinometer probe. The result showed that the inclinometer casing displaced around 20-25 mm after 6 months. It is believed that the soil mass moved insignificantly toward the river side. The factor of safe against sliding toward the river side was also 1.6, that is, the earth levee is stable.

\section{Discussions}

\section{Effects of the soilcrete walls on sliding stability of the earth levee}

Sliding of the tested earth levee was monitored using the inclinometer system including a $12-\mathrm{m}$ inclinometer casing and an inclinometer probe kit. The 12-m inclinometer casing was installed after the trial section constructed and locates at the single row soilcrete wall (Figure $6 a)$. The total length of the inclinometer casing was determined basing on the sliding analysis for the reinforced earth levee as shown in Figure 12. The potential critical failure surface located above the tip of the 12-m inclinometer casing about 2-3 $\mathrm{m}$ which is good enough to monitor lateral displacement of the soil mass $[11,12]$.

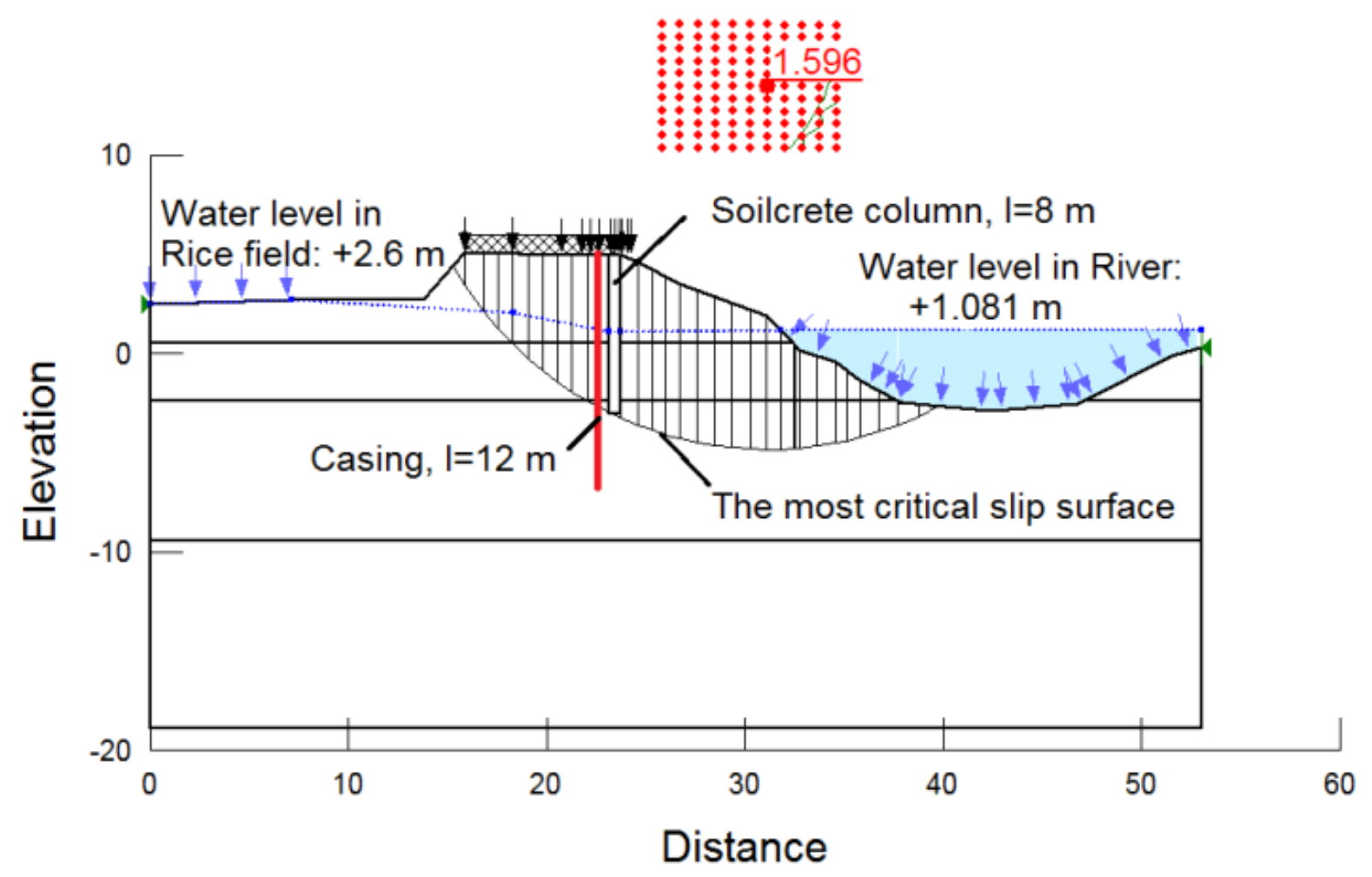

Figure 12 A critical circular failure surface with soilcrete reinforcement analyzed by the SLOPE/W software

Figure 11 shows the lateral displacement data monitored using the inclinometer kit from December 2014 to January 2015. Insignificant lateral displacement of the soil mass took place during the dry season which is from December to May every year $[11,13]$. In the dry season, the water level in the river has dropped appreciably and a counter force against sliding of the soil mass has reduced. However, the reinforced earth levee remains as stable when the accumulated lateral displacement was $20 \mathrm{~mm}$.

The results of sliding analysis using the field-monitored data by the SLOPE/W software are printed in Table 3. FS after reinforcement computed by the Simplified Bishop 
method is greater than 1.4 and the lowest value was at the lowest monitored water level in the river. In any circumstances, the earth levee is stable toward the rice field side. The analysis result recommends that the soilcrete walls can reinforce earth levees successfully against sliding.

\section{Effects of the soilcrete walls on seepage across the earth levee's body}

The groundwater observation data indicates that the tested section of the 2/9 earth levee is porous because the water level inside the earth levee was approximately the water levels in the river at the both observed cross sections before soilcrete reinforcement (Figure 9a). In general, groundwater levels in clayey soils are higher than water level in a river due to capillary [5]. When an earth levee has high porosity due to the least compaction during construction, water in a river can seep inside an earth levee via void spacing and makes groundwater levels similar the water level in the river. The water levels of the HK1 well were higher than those of others. It is thought that the HK1 could reach unusual confined groundwater (Figure 6).

The groundwater levels after reinforced by the soilcrete walls dropped markedly during the flood season that the water level in the river was higher the water level in the rice field (Figure 6b). It can be seen that the both single and double row soilcrete walls cut off effectively the floodwater seeping through the tested earth levee. The groundwater levels inside the earth levee maintained approximately the groundwater levels in the rice field. The groundwater monitoring data suggests that the soilcrete walls are quite uniform and low hydraulic conductivity. The hydraulic conductivity of the soilcrete walls is typically about $10^{-9} \mathrm{~m} / \mathrm{s}$ or lower [3] and is suitable to reinforce earth levees in Dong Thap province. The unusual groundwater level measured at the HK4 after reinforced was because the local authority raised the elevation of the earth levee using saturated sand. Water may infiltrate to the well and the clay soil mass surrounding the well may be more uniform than those of the other wells. As discussed earlier, the earth levee has high void space and was non-uniform due to lack of compaction. Therefore, groundwater levels may vary inconsistently.

\section{Conclusions}

The two field monitoring systems were built to supervise the field performance of the reinforced earth levee using the SCDM technology in Dong Thap province. This study investigated the effectiveness and feasibility of the SCDM technology applied to reinforce earth levees in the Mekong Delta. Eight groundwater observation wells were constructed to monitor groundwater across the tested earth levee before and after the trial section constructed. The 12-m inclinometer casing was installed after the trial section constructed at the single row soilcrete wall. The field monitored data was utilized for back analysis and assessed for the field performance of the trial construction. The results indicate that:

(1) The soilcrete walls were uniform even with the single row soilcrete wall.

(2) The soilcrete walls were successfully cut off seepage across the earth levee during the flood season.

(3) The soilcrete walls improved the sliding stability of the earth levee appreciably.

\section{Acknowledgement}

The authors acknowledge the AUN/SEED-NET (a JICA office in Thailand), Something Vietnam Co. Ltd., and An Giang province providing the research funds for the research project HCMUT CRI 1301-1401. Ho Chi Minh City University of Technology (HCMUT) and Dong Thap province have supported significantly the research team. 


\section{References}

[1] T.N. Hoi, Database of floodwater in the Mekong Delta for earth levee construction, HCMC, 2005. (in Vietnamese)

[2] Dong Thap People's Committee, Report on existing earth levees in Dong Thap province after the flood season 2011, No. 01/BC-UBND, 2012. (in Vietnamese)

[3] M. Kitazume, and M. Terashi, The Deep Mixing Method, CRC Press, London, United Kingdom, 2013.

[4] Las XD475, Report on Soil Investigation for the HCMUT CRI Research Project, 2013. (in Vietnamese)

[5] L.W. Abramson, T.S. Lee, S. Sunil, and B.M. Gleen, Slope Stability and Stabilization Methods, $2^{\text {nd }}$ Edition, John Wiley \& Sons Inc, New York, United States of America, 2002.

[6] Ministry of Transport, Design Guidelines for Highway on Soft Ground, 22 TCN 262-2000, 2002. (in Vietnamese)

[7] N.N. Du, Applying Field Monitoring Against Sliding of Structures Along Riverbanks in An Giang, Thesis (Master’s), Ho Chi Minh City University of Technology, Vietnam, 2013.

[8] L.K. Bao, L.P. Long, D.T.M Chinh, and T.N.H. Hung, "Laboratory investigation of soilcrete behaviors applying to reinforce earth levees in Dong Thap province," Journal of Construction, Vol. 6, No. 3, pp. 60-64, 2014a. (in Vietnamese)

[9] L.K. Bao, L.P. Long, and T.N.H. Hung, "Influences of soilcrete walls on seepage and sliding of earth levees in Dong Thap province,” Journal of Construction, Vol. 12, No. 7, pp. 66-70, 2014b. (in Vietnamese)

[10] L.P. Long, L.K. Bao, T.N.H. Hung, and Q.H. Chuong, "Quality assessment of field soilcrete using deep mixing method to reinforce earth levees or rural roads along riverbanks in Dong Thap province,” Journal of Construction, Vol. 1, No. 16, pp. 92-96, 2015. (in Vietnamese)

[11] H.H. Tran-Nguyen, and N.D. Nguyen, "Remedial structures to stabilize Long Xuyen riverbank to prevent sliding in An Giang province, Vietnam,” ASEAN Engineering Journal Part C, Vol. 3, No. 2, pp. 42-54, 2014.

[12] Slope Indicator Company, Guide to Geotechnical Instrumentation, Durham Geo Slope Indicator, Washington, United States of America, 2014.

[13] H.H. Tran-Nguyen, and V.X. Le, "Failures of highway embankments along the Hau riverbanks: Causes and remedial solutions," In: Proceedings of Geotechnics for sustainable development conference, Hanoi, Vietnam, pp. 909-916, 2011.

[14] J.M. Duncan, and S.G. Wright, Soil Strength and Slope Stability, John Wiley \& Sons, New Jersey, United States of America, 2005. 